\title{
IGF1 does not overcome sexual dimorphism of body and muscle size in Mstn-/- mice
}

\author{
Ryan Paul', Kim Whiteman², Shelley J Falconer³, Jenny M Oldham³, Ferenc Jeanplong ${ }^{3}$, Kenneth G Matthews ${ }^{3}$, \\ Heather K Smith4, Mark Thomas², Trevor Watson ${ }^{3}$ and Christopher D McMahon ${ }^{2,3}$
}

1 University of Auckland Waikato Clinical School, Hamilton, New Zealand

2ManukaMed LP, Hamilton, New Zealand

${ }^{3}$ AgResearch Ltd, Hamilton, New Zealand

${ }^{4}$ Department of Exercise Sciences, University of Auckland, Auckland Mail Centre, Auckland, New Zealand

Correspondence should be addressed to C D McMahon: mcmahonc@xtra.co.nz

\begin{abstract}
Insulin-like growth factor-1 (IGF1) is crucial for regulating post-natal growth and, along with myostatin (MSTN), regulates muscle size. Here, we sought to clarify the roles of these two genes in regulating sexually dimorphic growth of body and muscle mass. In the first study, we established that Igf1 mRNA was increased to a greater extent and Igf1 receptor mRNA increased earlier in male, than in female, gastrocnemius muscles during the rapid phase of growth (from 2 to 6 weeks) were unchanged, thereafter, to 32 weeks of age in WT mice $(P<0.001)$. In the second study, we sought to determine if supplemental IGF1 could overcome the sexual dimorphism of muscle and body mass, when myostatin is absent. We crossed myostatin null $\left(\mathrm{Mstn}^{-/-}\right)$mice with mice overexpressing Igf1 in skeletal muscle $\left(I g f 1^{+}\right)$to generate six genotypes; control $\left(\mathrm{Msth}^{+/+}\right)$,

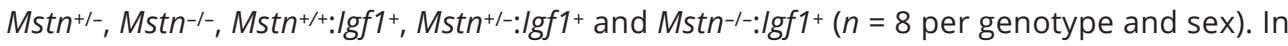
both sexes, body mass at 12 weeks was increased by at least 1.6-fold and muscle mass by at least 3-fold in Mstn-1-:Igf1+ compared with $\mathrm{Mstn}^{+/+}$mice $(P<0.001)$. The abundance of AKT was increased in muscles of mice transgenic for Mstn, while phosphorylation of AKTS473 was increased in both male and female mice transgenic for $\lg f 1^{+}$. The ratio of phosphorylated to total AKT was 1.9-fold greater in male mice $(P<0.001)$. Thus, despite increased growth of skeletal muscle and body size when myostatin was absent and IGF1 was in excess, sexual dimorphism persisted, an effect consistent with greater IGF1induced activation of AKT in skeletal muscles of males.
\end{abstract}

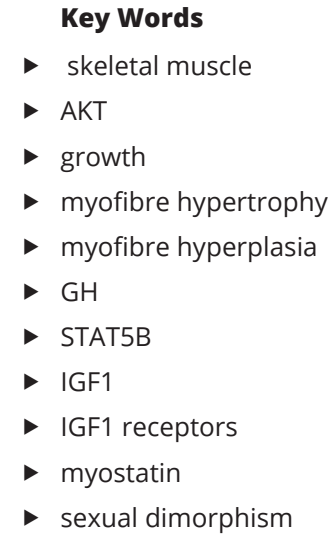

Journal of Endocrinology (2021) 248, 207-220

\section{Introduction}

Male mammals generally have a larger body size and muscle mass than females and, in mice, this arises from a faster rate of growth of muscle and bone before epiphysial closure (Griffin \& Goldspink 1973, Callewaert et al. 2010). Insulin-like growth factor-1 (IGF1) is widely recognised to be the major regulator of post-natal growth and sexually dimorphic growth (Baker et al. 1993, Liu et al. 1993, Lupu et al. 2001). Global deletion of IGF1 results in mice that are $70 \%$ smaller than WT controls as adults and sexual dimorphism of body size is lost (Baker et al. 1993, Liu \& LeRoith 1999, Lupu et al. 2001).

Growth hormone (GH) regulates the synthesis and secretion of IGF1. The premise is that GH acts on $\mathrm{GH}$ receptors to induced phosphorylation of the transcription factor STAT5B to regulate transcription of IGF1 (Le Roith et al. 2001). When STAT5B is absent, 
sexually dimorphic growth and the difference in body and muscle mass between male and female mice was initially shown to be eliminated (Udy et al. 1997, Oldham et al. 2009). However, a subsequent study showed that sexual dimorphism persisted but with much reduced amplitude (Paul et al. 2019). The growth deficit is more pronounced in humans, where naturally occurring loss-of-function mutations cause retardation of growth (Kofoed et al. 2003, Hwa 2016). Therefore, IGF1 is thought to be crucial, not only for regulating post-natal growth but also for regulating sexually dimorphic growth.

The source of IGF1 is also important. Locally produced IGF1 (including skeletal muscle), rather than liver derived, is now understood to have the dominant influence on post-natal growth because liver-specific deletion of IGF1 had no effect on post-natal growth of mice, despite reducing circulating concentrations of IGF1 by $75 \%$ (Sjogren et al. 1999, Yakar et al. 1999). Later studies also reported that IGF1 in skeletal muscle is likely to be the major contributor to post-natal growth, because genetic removal of Stat $5 a$ and $5 b$ from skeletal muscle reduced post-natal growth of mice (Klover \& Hennighausen 2007, Klover et al. 2009). In the same studies, no further loss of growth was observed when Stat $5 b$ was also eliminated from the liver (Klover \& Hennighausen 2007, Klover et al. 2009). While local expression of IGF1 is the predominant regulator of post-natal growth, circulating IGF1, derived from liver, accounts for about $30 \%$ of post-natal growth and adult body size (Stratikopoulos et al. 2008).

Myostatin, too, has a profound, but inhibitory, influence on the growth of skeletal muscle during embryogenesis and post-natal growth. Myostatin is present in skeletal muscle at the earliest stages of muscle development and inhibits myogenesis. In the absence of myostatin, mice have an increased number of myofibres (McPherron et al. 1997, Lee \& McPherron 1999) and an unaffected (Hennebry et al. 2017), or increased (McPherron et al. 1997, Amthor et al. 2007), size of muscle fibres depending on a given muscle. In contrast to the action on muscle, myostatin directs the fate of progenitor cells towards a lipogenic lineage (Artaza et al. 2005), thereby having a profound effect on body composition.

We and others have shown that myostatin protein is reduced in skeletal muscles of adult male mice (McMahon et al. 2003, Reisz-Porszasz et al. 2003) and that the reduction is regulated by GH acting on STAT5B (Oldham et al. 2009). We also reported that the posttranslational decrease in mature myostatin is initiated between 6 and 12 weeks of age in males and coincides with the onset of sexually dimorphic growth. From 6 weeks, the divergence in growth and abundance of mature myostatin protein between the sexes were more apparent, reaching the greatest difference when mice were 32 weeks of age. Therefore, we proposed that myostatin not only regulates the growth of skeletal muscles in post-natal life but also regulates sexually dimorphic growth and maintenance of the mass of adult skeletal muscles.

Myostatin and IGF1 have opposing actions on common and independent signal transduction pathways. Myostatin binds and activates activin type $2 \mathrm{~B}$ receptors to promote phosphorylation of SMAD2/3 (Rebbapragada et al. 2003) and inhibits RPS6KB1 and RPS6 to regulate protein synthesis (Trendelenburg et al. 2009, Welle et al. 2009). In contrast, IGF1 activates the IGF1 receptor and phosphorylates PI3 kinase (PI3K) and AKT (Rommel et al. 2001). The PI3K/AKT pathway is common to both factors and there is considerable crossregulation between the two, wherein myostatin inhibits AKT to block IGF1-induced hypertrophy of myotubes (Morissette et al. 2009), IGF1 inhibits myostatin-induced activation of SMAD3 (Retamales et al. 2015). Thus, the two factors, having opposing actions, could act in an additive, or synergistic manner via common, or distinct pathways to establish muscle and inhibit fat mass.

We have recently confirmed that both IGF1 and myostatin interact to regulate post-natal growth of body and muscle mass in male mice (Hennebry et al. 2017). In preliminary observations, we noticed that there was less $I g f 1 E a$ mRNA (the principal endogenous $I g f 1$ transcript) in quadriceps muscles of $\mathrm{Mstn}^{-1-}$ mice at 4 and 8 weeks of age (about half the amount) compared with WT (Mstn+/+) mice. Furthermore, there were lower concentrations of Igf1Ea mRNA after 8 weeks of age reaching similar concentrations by 20 weeks in both strains (Hennebry et al. 2017). Therefore, we proposed that rates of growth, body and muscle mass would be increased if IGF1 protein were increased in $\mathrm{Mstn}^{-/}$mice. Indeed, sequential removal of copies of the myostatin gene increased the number of myofibres and the addition of transgenic IGF1 in skeletal muscle increased the size of those myofibres, providing a synergistic increase in muscle mass, a reduction in fat mass and a shift in myofibre phenotype towards fastertwitch (Hennebry et al. 2017). We further showed that loss of myostatin increased the abundance of the cell signalling intermediate AKT, while additional IGF1 increased the phosphorylation of AKT. Therefore, both IGF1 and myostatin interact to regulate the signalling of AKT.

In the current study, we sought to determine the effect of the interaction of IGF1 and myostatin on AKT 
signalling and sexually dimorphic growth. We first examined the expression of $I g f I E a$ and $I g f 1$ receptors (Igf1r) in skeletal muscles and concentrations of IGF1 in blood during post-natal growth of male and female WT mice to determine the pattern of expression in post-natal muscle. In addition, we hypothesised that in the absence of myostatin and with IGF1 in excess, the rates of growth would be greater in both sexes and sexual dimorphism of body and muscle mass might be reduced, or abolished.

\section{Materials and methods}

\section{Animals}

\section{Study 1 Quantification of Igf1Ea and Igf1r mRNA in muscles of WT mice during post-natal growth from 2 to 32 weeks of age}

Male and female mice of the C57BL/6J strain were killed at $2,3,4,6,12,20$ and 32 weeks of age $(n=6$ of each sex per age).

\section{Study 2 Development of mice transgenic for Igf1 in skeletal muscles and myostatin}

Generation of $\mathrm{Mstn}^{-1-}$ mice (where all tissues lack expression of Mstn) has been previously described (McPherron et al. 1997). We obtained a breeding pair of thesemice as a gift from S-J Lee (Johns Hopkins University School of Medicine, Baltimore, MD, USA).

Transgenic Igf1 (C2:Ea) mice were generated at the European Molecular Biology Laboratory, Rome, Italy by $\mathrm{N}$ Winn and $\mathrm{N}$ Rosenthal. The MLC/Igf1 (C2:Ea) expression construct was generated by cloning the mouse Igf1 (C2:Ea) cDNA sequences into the previously described skeletal muscle-specific expression cassette containing the myosin light chain (MLC) 1/3 promoter, a SV40 polyadenylation signal, followed by the MLC1/3 enhancer sequence (Rosenthal et al. 1989, Musaro et al. 2001, Shavlakadze et al. 2010). In these MLC/Igf1 transgenic mice, IGF1 is most highly expressed in fasttwitch myofibres in the order $2 \mathrm{~B}, 2 \mathrm{X}$ and $2 \mathrm{~A}$ myosin heavy chain (MyHC) (Shavlakadze et al. 2005).

The Igf1 (C2:Ea) (FVB background) and Mstn-/(C57BL/6J background) mice were maintained as separate colonies at the Ruakura Research Centre, Hamilton, New Zealand. The F1 generation from a cross of Igf1 (C2:Ea) and $\mathrm{Mstn}^{-1-}$ founders was used to produce six genotypes in the F2 offspring: Mstn+/+ (no Igf1 transgene), Mstn+/-, $\mathrm{Mstn}^{-/}, \mathrm{Mstn}^{+/+}: \mathrm{Igf1}^{+}, \mathrm{Mstn}^{+/-: I g f 1^{+}}$and $\mathrm{Mstn}^{-/-: I g f 1^{+}}\left(\mathrm{Igf1}^{+}\right.$ refers to the Igf1 (C2:Ea) transgene).
For both studies, mice were housed $2-4$ per cage in a temperature controlled $\left(22^{\circ} \mathrm{C}\right)$ and light controlled $(12$ $\mathrm{h}$ light:12 h darkness cycle) animal facility at Ruakura Research Centre, Hamilton, New Zealand. Mice had access to a standard rodent chow (Specialty Feeds, Glen Forrest, WA 6071, Australia) and water ad libitum.

The studies were approved by the Ruakura Animal Ethics Committee.

\section{Phenotype analyses of six genotypes during early post-natal growth (sampled at 12 weeks of age) (study 2 only)}

Male $(n=48)$ and female $(n=48)$ pups with or without the Igf1 (C2:Ea) transgene that had a matching myostatin genotype $\left(\mathrm{Mstn}^{+/+}, \mathrm{Mstn}^{+/-}\right.$, or $\left.\mathrm{Mstn}^{--}\right)$within litters were included in the study ( $n=8$ per genotype and sex). Mice were weighed weekly and killed at 12 weeks of age and many tissues were sampled for molecular analyses as outlined below.

\section{Muscle and fat pad collection (studies 1 and 2)}

Mice were not fasted before death and were killed using $\mathrm{CO}_{2}$ asphyxiation followed by cervical dislocation. At death, a sample of blood was collected via cardiac puncture into a tube containing EDTA. Plasma was harvested and stored at $-20^{\circ} \mathrm{C}$ before the assay of IGF1.

Following euthanasia, the Quadriceps femoris (quadriceps), B. femoris, gastrocnemius, plantaris, soleus, Extensor digitorum longus (EDL), Tibialis anterior (T. anterior) muscles were excised from both hind limbs, along with the heart, which was blotted to remove excess blood, and weighed. The soleus is a slow-twitch muscle. The $T$. anterior, plantaris and $E D L$ are fast-twitch muscle and the quadriceps, B. femoris and gastrocnemius muscles have a mixed myofibre composition (Hamalainen \& Pette 1993, Augusto et al. 2004). Because mouse muscles are small and some were used in a previous study (Hennebry et al. 2017), we used the gastrocnemius for qPCR in study 1 and the quadriceps muscle for qPCR, Western analyses and myofibre typing for study 2 .

The length of the tibia was measured and used to normalise the mean masses of skeletal muscles (White et al. 2016) and the heart was normalised to body mass (Hagdorn et al. 2019). The gonadal fat pads were excised and weighed and were expressed as a percent of body mass. The gonadal fat pads correlate highly with total body fat (Rogers \& Webb 1980). 
Table 1 Primers used for qPCR (studies 1 and 2).

\begin{tabular}{|c|c|c|c|c|}
\hline Gene & Primer sequences & Size (bp) & Annealing $\left({ }^{\circ} \mathrm{C}\right)$ & GenBank Accession \\
\hline \multirow[t]{2}{*}{ Igf1Ea } & Fwd: GCTTGCTCACCTTTACCAGC & 301 & 60 & NM_001111275.2 \\
\hline & Rev: AAATGTACTTCCTTCTGGGTCT & & & \\
\hline \multirow[t]{2}{*}{$\operatorname{lgf1}(\mathrm{C} 2: \mathrm{Ea})^{*}$} & Fwd: ACTGACATGCCCAAGACTCAG & 283 & 60 & Shavlakadze et al. 2010 \\
\hline & Rev: ATTCCACCACTGСTCCCATTC & & & \\
\hline \multirow[t]{2}{*}{$\lg f 1 r$} & Fwd: CTGCGGCGATGAAGAGAAGAAAA & 546 & 60 & NM_010513.2 \\
\hline & Rev: ACCGGTGCCACGTTATGATGATT & & & \\
\hline
\end{tabular}

*Fwd primer is common to exon 4, while the reverse primer is for the SV40 enhancer of the transgene.

RNA extraction and quantitative (q) PCR (studies 1 and 2)

Total RNA was extracted from the gastrocnemius (study 1) and from the quadriceps muscles (study 2) using Trizol reagent (Invitrogen). cDNA was reverse transcribed (RT) from $2 \mu \mathrm{g}$ total RNA using qSCRIPT (Quanta BioSciences, Maryland, USA) as described previously (Smith et al. 2014). In study 1 , qPCR was carried out using a Lightcycler 2.0 (Roche Diagnostics) and Roche Faststart DNA master PLUS SYBR Green I mix (Roche Diagnostics). In study 2, qPCR was carried out using a RotorGene 6000 (Corbett Research, Bio-Strategy Limited). The primers for $I g f 1 E a$, Igf1 (C2:Ea) and Igf1 receptor are presented in Table 1. Standard curves were established by serial dilution of a pool of cDNA obtained from each sample and results were normalised to the concentration of ssDNA in the RT samples (Lundby et al. 2005).

\section{Western blot analyses (study 2 only)}

Protein was extracted from the quadriceps muscle and Western blotting was performed as previously described (Smith et al. 2014). Membranes were incubated with rabbit anti-AKT1/2/3 (1:3000, \#8312, Santa Cruz Biotechnology, Inc.), rabbit anti-phospho-AKT1 ${ }^{\text {S473 }}$ monoclonal (1:10,000, \#44-621G, Invitrogen) and rabbit monoclonal anti-GAPDH (1:10,000, \#EPR16891, Abcam) and the abundance of each protein was detected with enhanced chemiluminescence. GAPDH was used as a loading control. The images were captured with a ChemiDoc MP Imaging System (Bio-Rad Laboratories (NZ) Pty Ltd) and the optical densities of each immunoreactive band were obtained using Image Lab software (Bio-Rad Laboratories (NZ) Pty Ltd).

\section{Assessment of myosin heavy chain isoforms (MyHC) (study 2 only)}

Changes in the composition of MyHC in quadriceps muscles were determined electrophoretically as described

\begin{tabular}{|lr} 
https://joe.bioscientifica.com & ( 2021 Society for Endocrinology \\
https://doi.org/10.1530/JOE-20-0485 & Published by Bioscientifica Ltd. \\
Printed in Great Britain
\end{tabular}

previously (Smith et al. 2014). Despite improvements in separation of the bands using an $8 \mathrm{M}$ urea/2 $\mathrm{M}$ thiourea buffer in which the samples were loaded, the $2 \mathrm{~A}$ and $2 \mathrm{X}$ bands typically do not separate as cleanly in mouse skeletal muscle as they do in rat skeletal muscle (Blough et al. 1996). Therefore, we measured MyHC 2A and 2X as one band. A 50:50 mixture of mouse soleus and $E D L$ muscle were run in the gels to act as a marker to help identify MyHC bands.

\section{IGF1 assay (Studies 1 and 2)}

Concentrations of IGF1 protein were assayed in plasma in both studies and in homogenates from quadriceps muscles in study 2 using a mouse/rat IGF1 ELISA kit (\#MG100, Quantikine ELISA, R\&D Systems Inc). Concentrations of IGF1 were normalised to the concentration of total protein (measured by BCA assay) in the homogenate of quadriceps muscles.

\section{Statistical analysis}

All data were analysed with Prism version 8.3.0 for Windows, GraphPad Software. In study 1, two-way ANOVA was used with sex and time as the treatment terms. Post hoc analyses were made with Fisher's Uncorrected LSD test because multiple comparison among means were not required. In study 2, three-way ANOVA was used with IGF1, MSTN and Sex as the treatment terms. Posthoc analyses were made with Tukey's multiple comparison test and with Fisher's Uncorrected LSD test when multiple comparisons were and were not required, respectively. Data are presented as means and the S.E.M.

\section{Results}

\section{Study 1}

\section{Rate of growth}

In study 1, body mass (Fig. 1A) and the mass of gastrocnemius muscles (Fig. 1B) increased equally in both sexes until 
A

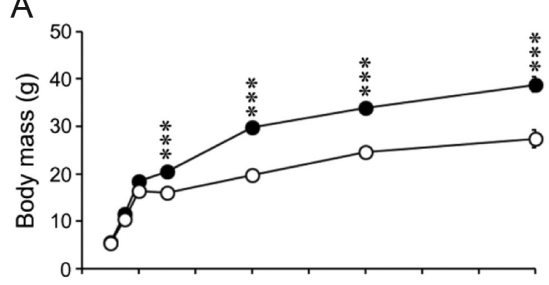

C

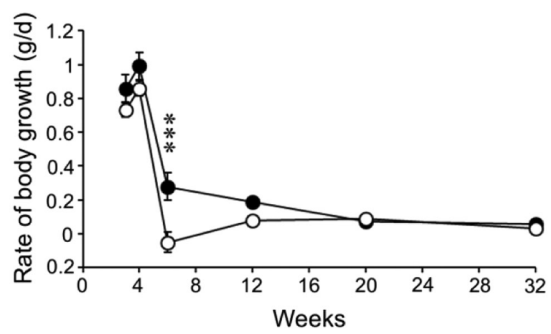

$\mathrm{B}$
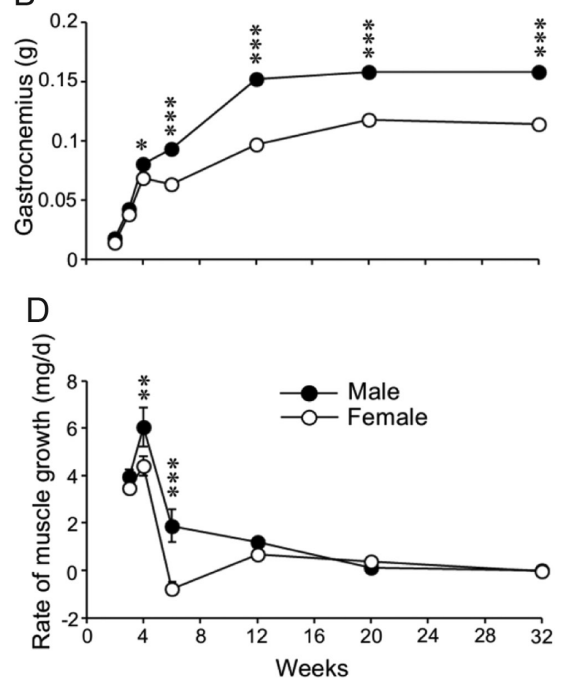

\section{Figure 1}

Body and muscle mass and rates of growth dynamics in WT mice during post-natal growth (study 1). (A) body mass (mean \pm S.E.M.), (B) gastrocnemius mass, $(C)$ growth rate of body mass and (D) growth rate of gastrocnemius mass in male and female mice of the C57 strain from 2 to 32 weeks of age ( $n=6$ per group). Asterisks indicate significance between sex at each time point $(* P<0.05, * * P<0.01, * * * P<0.001)$.
4 weeks of age, after which there was a precipitous decline in the rates of growth of body and muscle mass in both sexes, with a greater reduction in females than in males (Fig. 1C and D).

\section{Expression of Igf1Ea and Igf1r mRNA}

Igf1Ea mRNA increased in the gastrocnemius muscles of both sexes but to a greater extent (about two-fold) in muscles of males, than females, with peak expression observed at 6 weeks of age, before declining in both sexes to 32 weeks of age (Fig. 2A). In contrast, Igf1r mRNA increased equally in the gastrocnemius muscles of both sexes but peaked earlier at 4 weeks in males and later at 6 weeks in females (Fig. 2B).

\section{Concentrations of IGF1 protein in plasma}

Concentrations of IGF1 protein in plasma were not significantly different across time or between male and female mice. However, a bimodal pattern of was evident in blood, wherein concentrations were increased between 3 and 4 weeks and again at 20 weeks. The first peak coincided with the increased rate of body and muscle mass (Fig. 3).

\section{Study 2}

\section{Expression of transgenic Igf1Ea mRNA}

We confirmed that the $I g f 1$ transgene was expressed in quadriceps muscles of the Mstn+/+:Igf1+, Mstn ${ }^{+-}: I g f 1^{+}$and Mstn $^{-/-}: I_{8 f 1^{+}}$mice and absent in those of $\mathrm{Mstn}^{+/+}$, Mstn ${ }^{+/-}$ and $\mathrm{Mstn}^{-/-}$mice (Fig. 4A). In addition, we observed that expression of the Igf1 transgene was two- to fourfold higher in quadriceps muscles of males, than females
$(P<0.001)$. Furthermore, expression of the Igf1 transgene increased in males, but not females, as copy number of the myostatin gene decreased (MSTN $\times$ Sex $\times$ IGF1 interaction, $P<0.01$ ) (Fig. 4A). Similarly, concentrations of IGF1 protein were increased in quadriceps muscles of mice transgenic for Igf1 (main effect of IGF1, $P<0.001$ ). However, female quadriceps muscles had 1.4-fold more
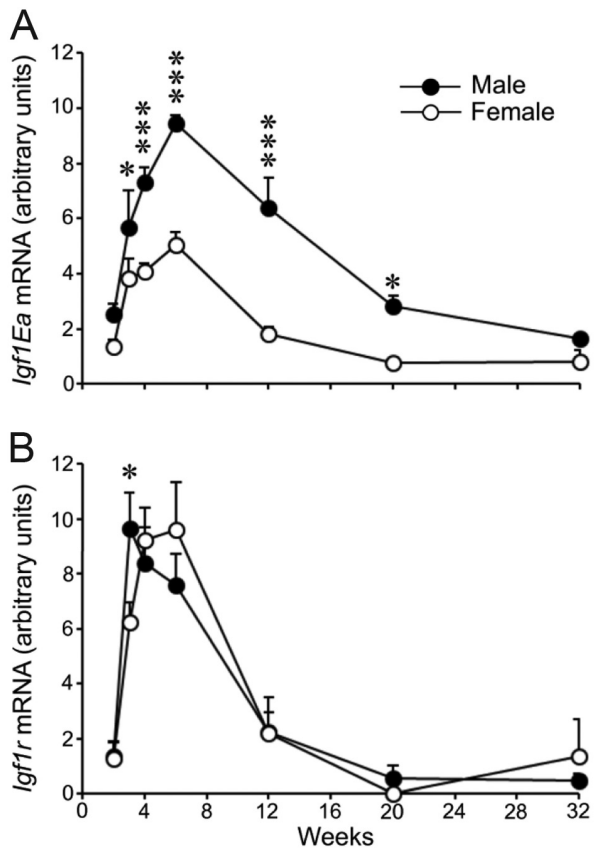

Figure 2

Concentrations of mRNA in gastrocnemius muscles of WT mice during post-natal growth (study 1). Arbitrary concentrations (mean \pm S.E.M.) of (A) Igf1Ea mRNA and (B) Igf1 receptor mRNA in gastrocnemius muscles of male and female C57 mice from 2 to 32 weeks of age as determined by qPCR ( $n=6$ per group). Asterisks indicate significance between sex at each time point $(* P<0.05, * \star * P<0.001)$. 


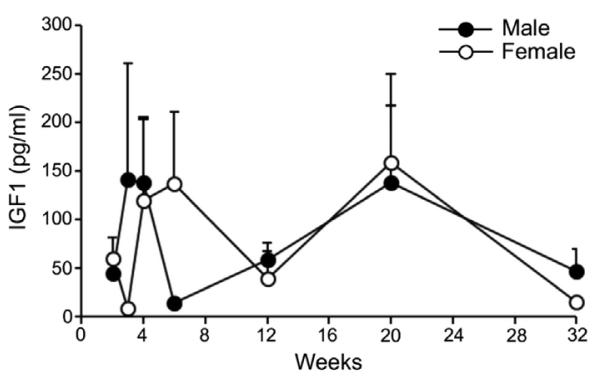

Figure 3

Concentrations of IGF1 (mean \pm S.E.M.) in plasma of male and female WT mice from 2 to 32 weeks of age as determined by ELISA ( $n=6$ per group) (study 1).

IGF1 protein across all genotypes than males (Sex $\times$ IGF1 interaction, $P<0.01$ ) (Fig. 4B).

\section{Phenotype of mice transgenic for IGF1 and absence of myostatin}

Sequential removal of myostatin together with overexpression of $I g f 1$ mRNA increased the rate of growth of both sexes with an increase of $\sim$ three-fold from the $\mathrm{Mstn}^{+/+}$
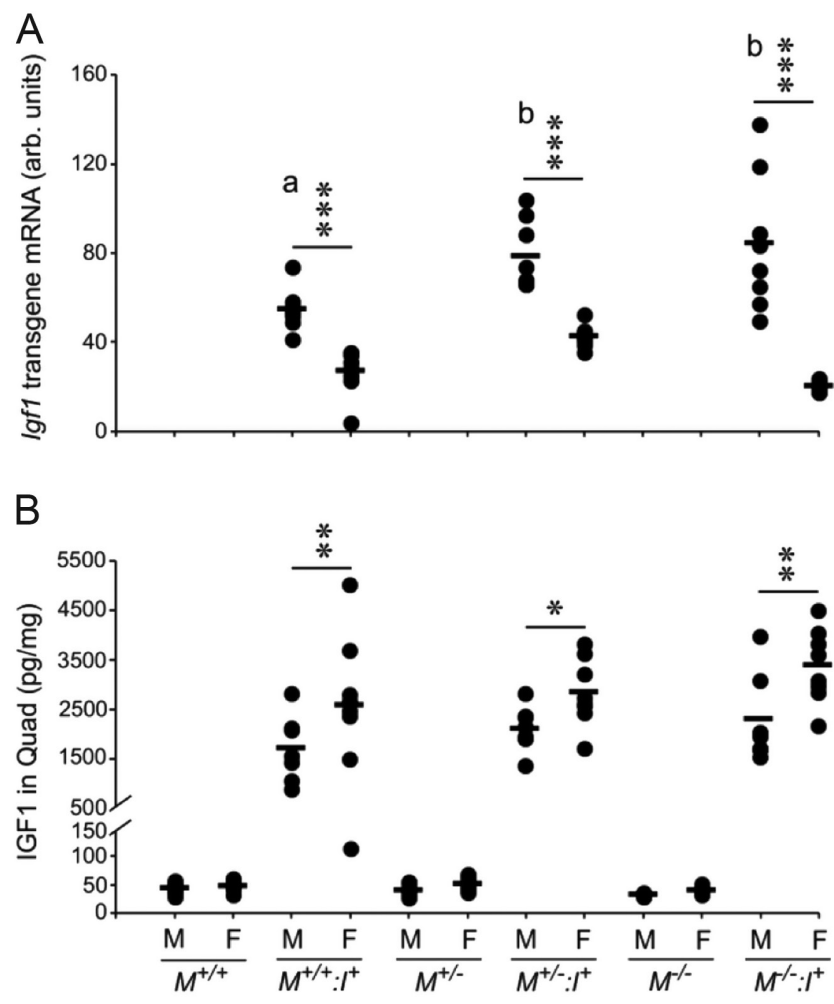

Figure 4

Concentrations of (A) Igf1Ea mRNA and (B) IGF1 protein in quadriceps muscles of $\mathrm{Mstn}^{+/+}\left(\mathrm{M}^{+/+}\right), \mathrm{Mstn}^{+/-}\left(\mathrm{M}^{+/-}\right), \mathrm{Mstn}^{-/-}\left(\mathrm{M}^{-/-}\right), \mathrm{Mstn}^{+/+}: \operatorname{lgf1}^{+}\left(\mathrm{M}^{+/+}: \mathrm{I}^{+}\right)$,

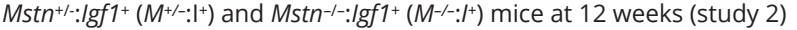
( $n=8$ per genotype and sex). The mean concentration for each group is represented by the horizontal bar. Asterisks indicate significance between sex within each genotype $(* P<0.05, * * P<0.01, * * * P<0.001)$.

(C) 2021 Society for Endocrinology Published by Bioscientifica Ltd. Printed in Great Britain to the $\mathrm{Mstn}^{-1-}: \mathrm{Igf1}^{+}$genotype $(P<0.001)$ (Fig. 5A). The main effects of MSTN, Sex and IGF1 accounted for $48.6 \%$ $(P<0.001), 20.4 \%(P<0.001)$ and $12.7 \%(P<0.001)$ of the variation, respectively. In addition, the rate of growth was 1.6-fold faster in males compared with females as copies of Mstn were removed and this interaction accounted for a further $2 \%$ of the variation (MSTN $\times$ Sex interaction, $P<0.01)$. Furthermore, the rate of growth was 1.4 -fold faster in mice transgenic for Igf1 as copies of Mstn were removed, which accounted for a further $6.6 \%$ of the variation $($ MSTN $\times$ IGF1 interaction, $P<0.001$ ) .

Similarly, body mass increased by at least 1.6 -fold overall in both sexes from the $\mathrm{Mstn}^{+/+}$to the $\mathrm{Mstn}^{-/-}: \mathrm{Ig}_{\mathrm{f} 1^{+}}$ genotype $(P<0.001)$, with MSTN, Sex and IGF1 accounting for $39.5 \%(P<0.001), 24.9 \%(P<0.001)$ and $13.8 \%(P$ $<0.001$ ) of the variation, respectively (Fig. 5B). The Igf1 transgene increased body mass by 1.2-fold irrespective of sex as copies of Mstn were removed and accounted for a further $2.6 \%$ of the variation $(\mathrm{MSTN} \times \mathrm{IGF} 1$ interaction, $P<0.01)$.

Females were shorter than males by $\sim 5 \%$ overall (main effect of Sex, $P<0.001$ ). In addition, there was a small (2\%) increase in body length (nose to anus) attributed to the absence of Mstn $(P<0.05)$ but no difference among genotypes for length of the tibia (Table 2). Therefore, the increase in body mass could be largely attributed to greater growth of skeletal muscles (Fig. 5C and Table 2). The mass of quadriceps (Fig. 5C) as well as the gastrocnemius, $B$. femoris, T. anterior, EDL and plantaris muscles at 12 weeks of age (corrected to tibia length) were increased by up to three-fold in male Mstn-/-:Igf1+ mice and up to 3.5-fold in female $M s t n^{-1-}: I g f 1^{+}$mice (Table 2). The uncorrected mass of the hearts was not different among genotypes but was significantly lower in female, than in male mice $(P<0.001)$. Conversely, the mass of the heart corrected to body mass was not different between sexes but was reduced in the absence of myostatin $(P<0.001)$ and in mice transgenic for $I g f 1$ $(P<0.001)$ (Table 2$)$. The mass of the gonadal fat pad was reduced in both sexes by $58 \%$ as copies of Mstn were reduced, which accounted for $17.5 \%$ of the variation (Fig. $5 \mathrm{D}, P<0.001)$. In addition, mice transgenic for Igf1 had $34 \%$ less gonadal fat than mice without the transgene (6.9\% of the variation, $P<0.01$ ).

Despite these dramatic increases in growth rate and body size, sexual dimorphism was not abolished and the differences remained remarkably constant across the genotypes, with males having a body mass that was $25 \%$ larger $(P<0.001)$ than females within each genotype (Fig. 5B). Similarly, mass of the quadriceps was 

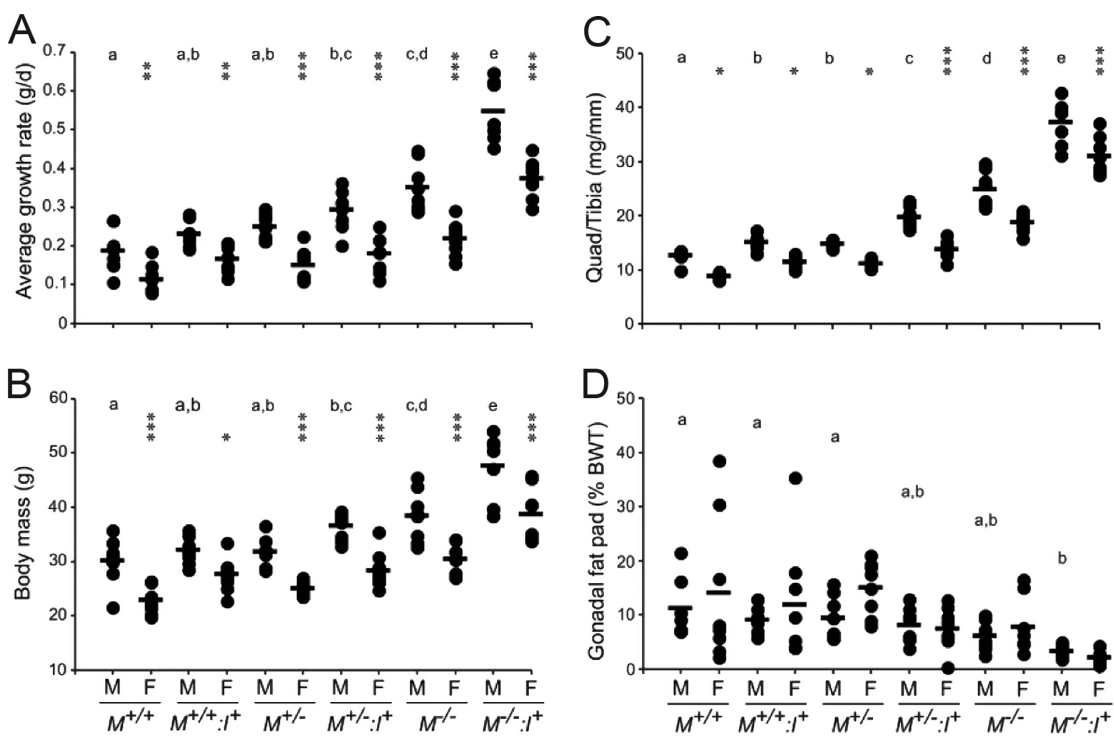

Figure 5

Rates of growth, body, muscle and fat mass of WT and transgenic mice (study 2). (A) Average rate of growth, (B) Body mass, (C) Mass of the quadriceps muscle normalised to tibia length and (D) mass of the gonadal fat pad normalised to body mass in $\mathrm{Mstn}^{+/+}\left(\mathrm{M}^{+/+}\right), \mathrm{Mstn}^{+/-}\left(\mathrm{M}^{+/-}\right), \mathrm{Mstn}^{-/-}\left(\mathrm{M}^{-/-}\right)$, Mstn $^{+/+}:$:gf1+ $\left(\mathrm{M}^{+/+}: \mathrm{I}^{+}\right)$, Mstn $^{+/-}: \lg 1^{+}\left(\mathrm{M}^{+/-}: \mathrm{I}^{+}\right)$and Mstn-/-: $/ g f 1^{+}\left(M^{-/-}: I^{+}\right)$mice at 12 weeks of age $(n=8$ per genotype and sex). The mean concentration for each group is represented by the horizontal bar. Unlike letters denote significant differences between genotype (at least $P<0.05$ ). Asterisks indicate significance between sex within genotype $\left({ }^{*} P<0.05, * \star P<0.01, * \star \star P P<0.001\right)$. on average $34 \%$ larger in males than in females $(P<$ 0.001) within each genotype (Fig. 5C). A similar pattern was evident for other muscles composed of fast- or mixedtwitch myofibres (Table 2). Overall, the absence of Mstn had the greatest effect on muscle mass (accounting for $64 \%$ of the variance on average), followed by the Igf1 transgene (15.4\% of the variance) and then sex $(7.8 \%$ of the variance) for quadriceps, gastrocnemius, B. femoris, $T$. anterior, EDL and plantaris muscles. The effect of the Igf1 transgene in conjunction with absence of Mstn (MSTN $\times$ IGF1 interaction) accounted for $7.9 \%$ of the variance, while the interaction of MSTN $\times$ Sex (gastrocnemius and plantaris) and IGF1 $\times$ Sex (T. anterior) accounted for $1.3 \%$ and $0.9 \%$ of the variance (Table 2 ).

The mass of the soleus was also increased, although to a lesser degree (up to two-fold increase) than muscles expressing the fast $2 \mathrm{X}$ and $2 \mathrm{~B}$ myosin heavy chains (Table 2 ). However, the mass of the soleus remained $\sim 30 \%$ larger in males than in females of all genotypes.

\section{Myofibre composition}

There was a main effect of sex $(P<0.001)$ on myofibre composition, wherein males had more MyHC type 2B and less type 2A/X (these bands did not separate during electrophoresis) and type I than female quadriceps muscles. In addition, there was a main effect of myostatin $(P<0.001)$ wherein deletion of myostatin biased the myofibre type composition in the quadriceps towards $2 \mathrm{~B}$ MyHC (9\% more in males and $11 \%$ more in females, $P<0.001$, Fig. 6A and C). By contrast, the abundance of type 2A/X MyHC in quadriceps was reduced by $70 \%$ in male and $65 \%$ in female Mstn $^{-/-}: I_{\delta} f 1^{+}$compared with
$\mathrm{Mstn}^{+/+}$controls (Fig. 6B, $P<0.001$ ), with a similar pattern occurring with type 1 MyHC (Fig. 6D, $P<0.001$ ).

\section{Concentrations of IGF1 protein in plasma and Igf1r mRNA in quadriceps}

We measured concentrations of IGF1 protein in blood to determine if IGF1 was getting into circulation to affect other tissues. Concentrations were increased $\sim 1$.4-fold) in plasma of male mice transgenic for Igf1 (Sex $\times$ IGF1 interaction, $P<0.001$ ) but not different between sexes in the other genotypes (Fig. 7A).

Concentrations of $I g f 1$ receptor mRNA were quite variable within sex and genotype. However, there was a MSTN $\times$ Sex $\times$ IGF1 interaction $(P<0.001)$, wherein concentrations were increased in female quadriceps muscles of $\mathrm{Mstn}^{+/+}, \mathrm{Mstn}^{+/-}: \mathrm{Igf1}^{+}, \mathrm{Mstn}^{-/}$and reduced in muscles of both sexes of Mstn ${ }^{--}: I g f 1^{+}$mice(Fig. 7B).

\section{Abundance of tAKT and pAKT}

The abundance of total ( $\mathrm{t})$ AKT increased in quadriceps muscles of male and female mice as copies of Mstn were removed to a maximum of 1.7- and 1.9-fold, respectively, from the $\mathrm{Mstn}^{+/+}$to the Mstn ${ }^{-/}: I g f 1^{+}$genotype (main effect of MSTN, $P<0.05$, Figs 8 and 9A). Furthermore, the abundance of tAKT tended to be 1.25 -fold greater $(P<0.1)$ in quadriceps muscles of female than male mice. In contrast, the abundance of phosphorylated (p) AKT was increased in mice of both sexes transgenic for Igf1 $(P<0.001)$ (Figs 8 and 9B). Overall, however, the ratio of p-t AKT was 1.9-fold greater (main effect of Sex, $P<0.001$ ) in quadriceps muscles of male than in female mice (Figs 8 and 9C). 


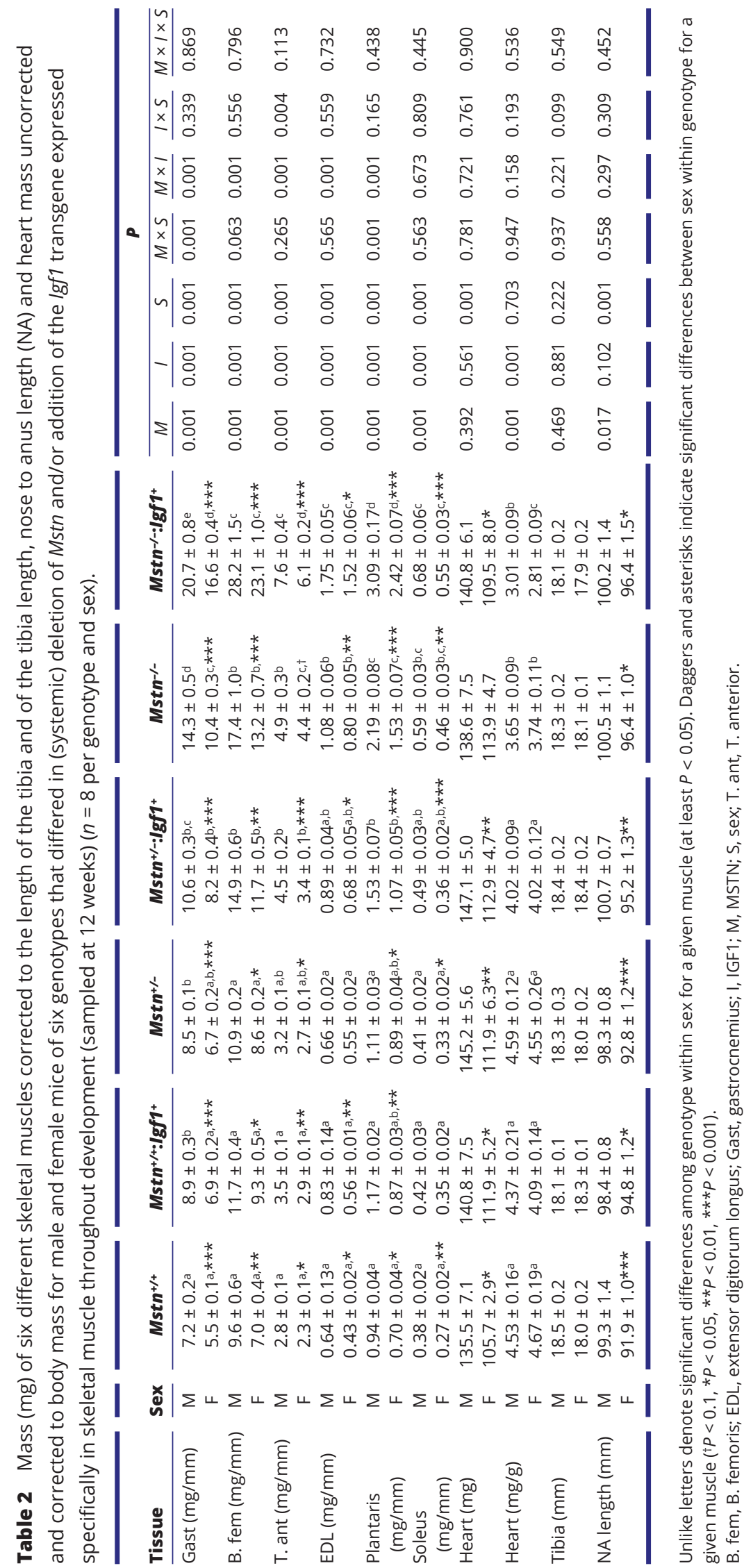


A
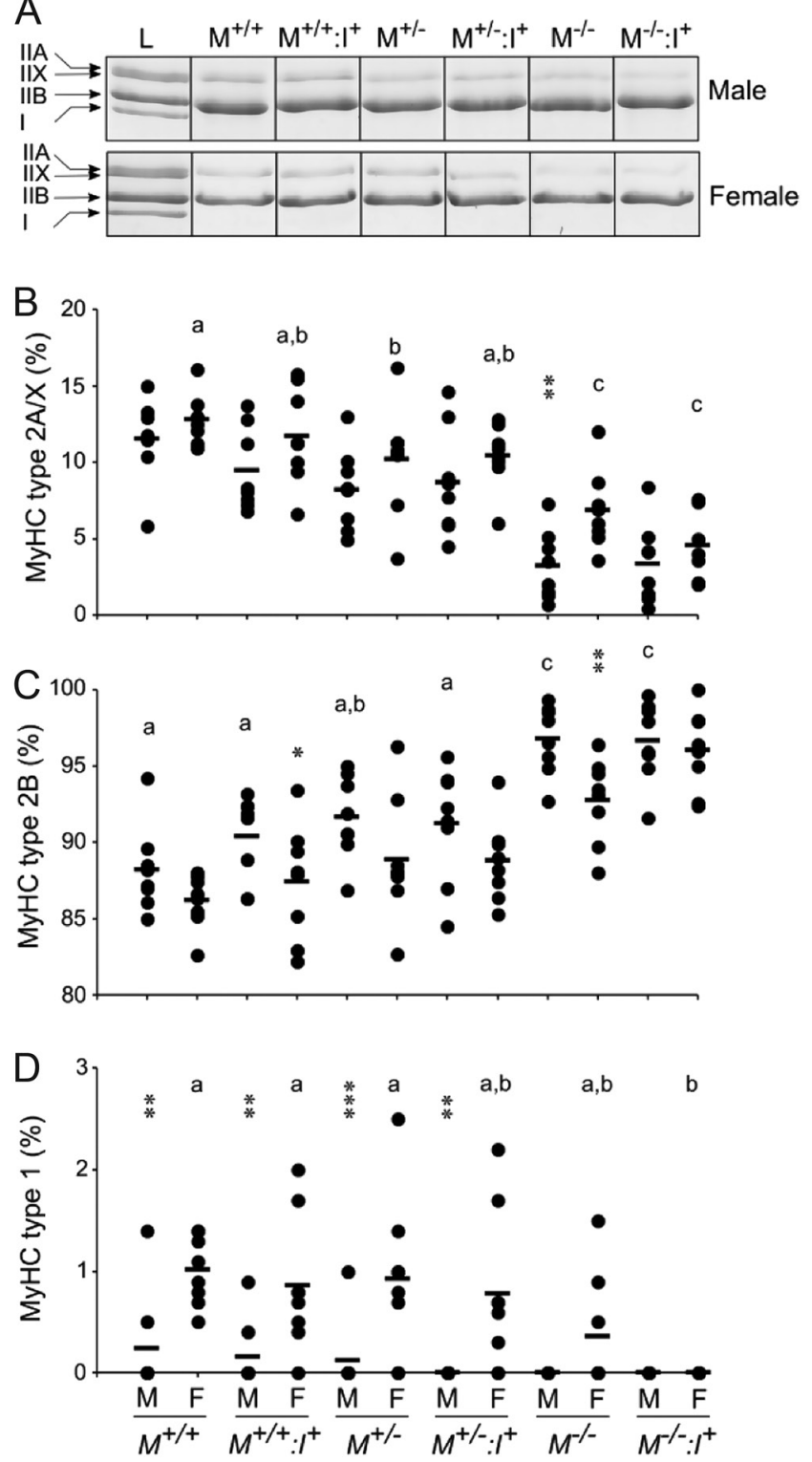

Figure 6

Myofibre phenotype of WT and transgenic mice at 12 weeks (study 2). (A) A representative image of an SDS-PAGE gel showing the separation of myosin heavy chains (MyHC). The control sample ( $\mathrm{L}$ ) was from a 50:50 mixture of soleus and $E D L$ muscles from mice for use as a reference. (B) Percent of MyHC 2A/X, (C) MyHC 2B and (D) MyHC 1 from the optical densities (OD) in quadriceps muscles of male and female $M s t n^{+/+}\left(M^{+/+}\right)$, Mstn $^{+/-}\left(\mathrm{M}^{+/-}\right)$, Mstn $^{-/-}\left(\mathrm{M}^{-/-}\right), \mathrm{Mstn}^{+/+}: \lg f 1^{+}\left(\mathrm{M}^{+/+}: \mathrm{I}^{+}\right), \mathrm{Mstn}^{+/-}: \operatorname{lgf1}^{+}\left(\mathrm{M}^{+/-}: \mathrm{I}^{+}\right)$and Mstn ${ }^{-/-}: \lg f 1^{+}\left(M^{---}: l^{+}\right)$mice ( $n=8$ per genotype and sex). The mean concentration for each group is represented by the horizontal bar. Unlike letters denote significant differences between genotypes (at least $P<0.05)$. Asterisks indicate significance between sex within genotype $\left({ }^{*} P<0.05, * \star P<0.01, * \star * P<0.001\right)$.

\section{Discussion}

We show here that increased expression of $I g f 1 E a$ and $I g f 1 r$ mRNA in gastrocnemius coincides with the most rapid rate
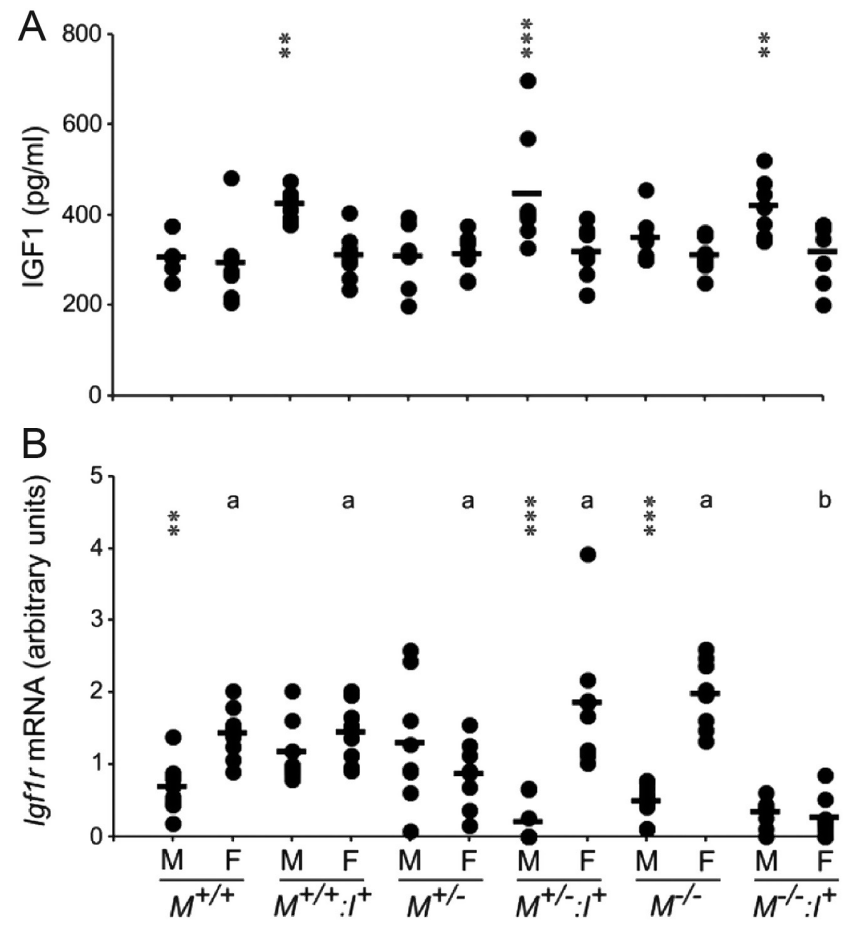

Figure 7

Concentrations of IGF1 protein in plasma (A) and arbitrary concentrations of Igf1 receptor mRNA (B) in quadriceps muscles of male and female $\mathrm{Mstn}^{+/+}\left(\mathrm{M}^{+/+}\right), \mathrm{Mstn}^{+/-}\left(\mathrm{M}^{+/-}\right), \mathrm{Mstn}^{-/-}\left(\mathrm{M}^{-/-}\right), \mathrm{Mstn}^{+/+}:$lgf1+ $\left(\mathrm{M}^{+/++}: /^{+}\right), \mathrm{Mstn}^{+/--}:$lgf1+ $\left(M^{+/-}: I^{+}\right)$and $M s t n^{-/-}: \lg 1^{+}\left(M^{-/-}: I^{+}\right)$mice $(n=8$ per genotype and sex, sampled at 12 weeks - study 2). The mean concentration for each group is represented by the horizontal bar. Asterisks indicate significance between sex within genotype $\left({ }^{*} P<0.01, * \star \star P<0.001\right)$. Unlike letters denote significant differences among genotypes ( $P$ at least $<0.05$ ).

of body growth and accretion of muscle mass in both male and female WT mice (study 1). The decline in expression of both genes after 6 weeks of age suggests that minimal transcription of these genes is required to maintain adult body and muscle mass, and/or that other factors are responsible for maintaining the mass of adult tissues. The pattern of $I g f 1 E a$ and $I g f 1 r$ mRNA in gastrocnemius muscles is broadly consistent with that of concentrations of IGFI protein in blood, although the amplitude of the latter is greatly reduced.

While concentrations of IGF1 protein in blood were not significantly different between sexes, or across time, the early peak is broadly consistent with the noted peripubertal increase in rodents between 4 and 6 weeks of age (Handelsman et al. 1987, Mathews et al. 1988, Hu et al. 1993). Puberty in mice occurs around 4.5 weeks (Safranski et al. 1993). The lack of differences between the sexes is consistent with local IGF1 playing the dominant role in regulating post-natal growth (Sjogren et al. 1999, Yakar et al. 1999, Klover \& Hennighausen 2007). 


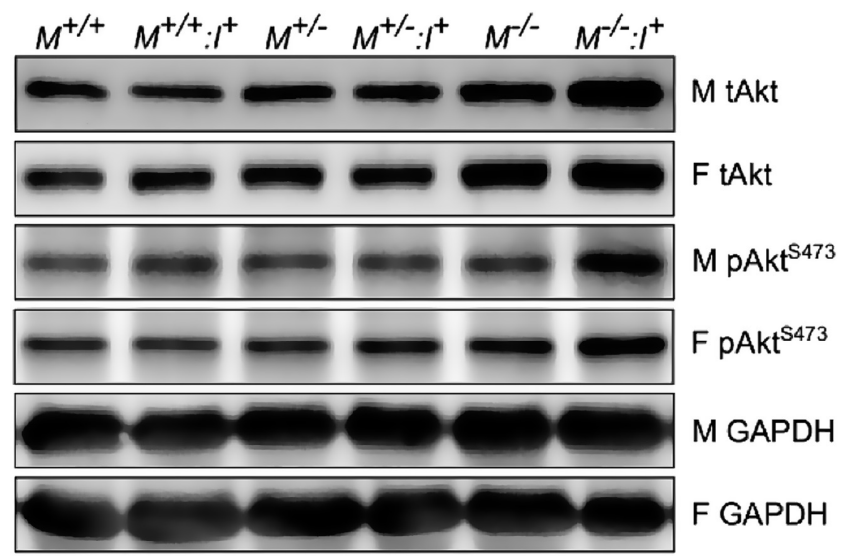

Figure 8

Representative Western blots of total (t) AKT, pAKTs473 and GAPDH in quadriceps muscles of male (M) and female (F) Mstn+/+ $\left(M^{+++}\right), M^{2} n^{+/-}\left(M^{+/-}\right)$,

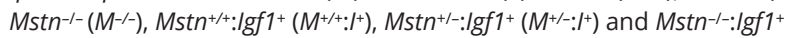
$\left(M^{--I^{+}}\right)$mice $(n=8$ per genotype and sex, sampled at 12 weeks - study 2$)$.

The timing of the increased expression of IgfIEa mRNA in skeletal muscle, and the increase in concentrations in blood observed here and noted by others above, occurs after the mitotic phase of myogenesis, which, in mice, is completed within 3 weeks of post-natal life (Beilharz et al. 1992). This is consistent with IGF1 acting to increase hypertrophy of muscle fibres rather than regulating hyperplasia. In contrast, reduced abundance, or absence of myostatin increases hyperplasia of myofibres (Hennebry et al. 2017).

Our finding here of a lower expression of Igf1 mRNA and delayed peak in $I g f 1 r$ mRNA in skeletal muscles of juvenile female mice indicated that greater growth might occur if $I g f 1$ expression was increased during post-natal growth. Moreover, we had anticipated that growth of body and muscle mass may be greater in females than in males and that the difference in sexual dimorphism of body size would be reduced, or abolished in the current study. However, while transgenic mice had greater rates of body growth and eventual body and muscle mass, the difference in sexually dimorphic size persisted. Indeed, the mass of female $\mathrm{Mstn}^{---: I g f 1^{+}}$mice was $\sim 30 \%$ greater, and the mass of the quadriceps was 2.5-fold greater, than male $\mathrm{Mstn}^{+/+}$mice. However, within genotype, females remained $\sim 25 \%$ smaller than males with a similar reduction in muscle mass than that of males.

The expression of the Igf 1 transgene, driven by the MLC promoter, is activated after 10 days post-partum (Musaro et al. 2001). Therefore, the increased production and availability of transgenic IGF1 early in post-natal skeletal muscle likely exacerbates the increase in mass of growing muscles. In confirmation, we found that

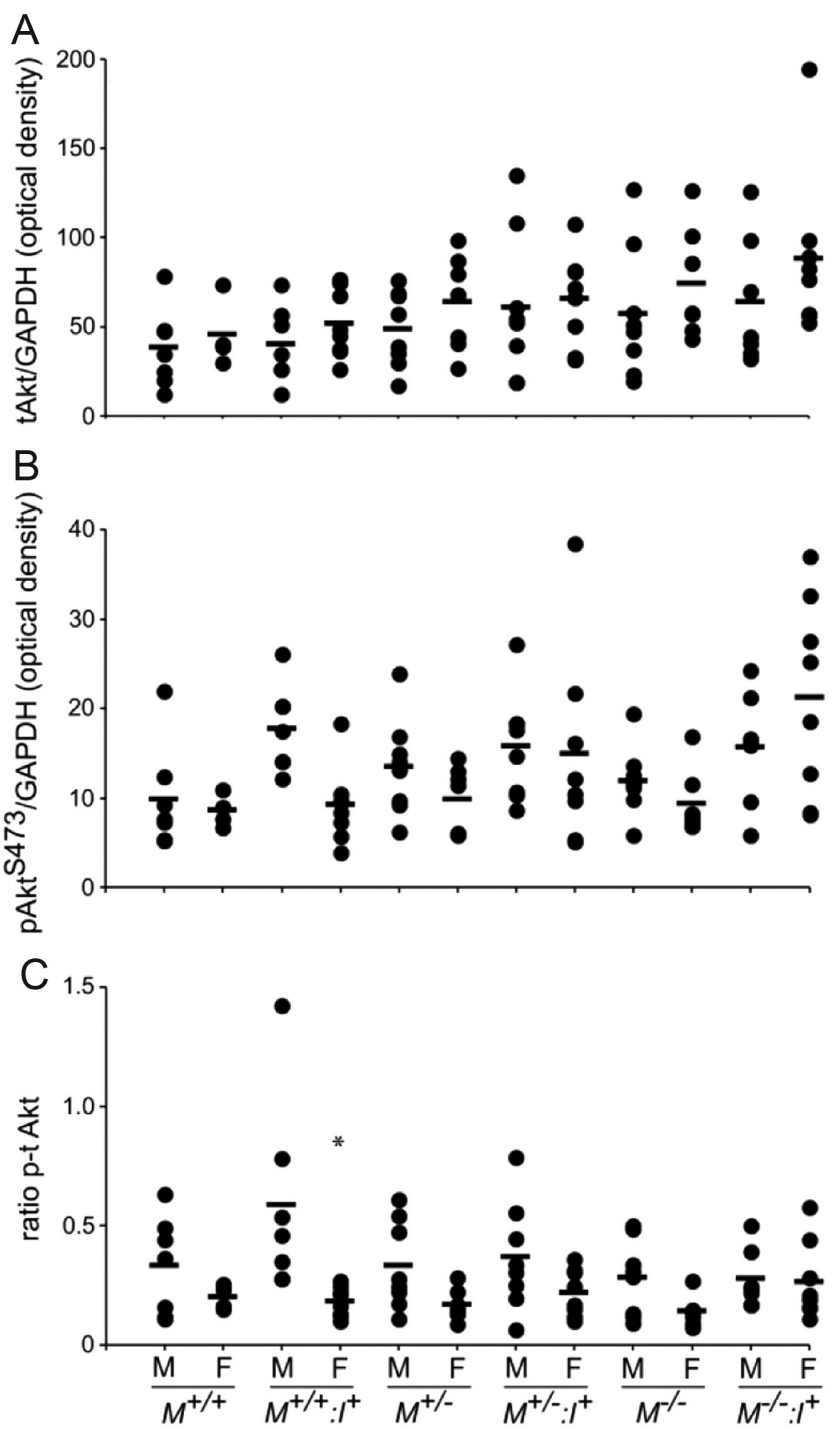

Figure 9

Optical densities of (A) total (t) AKT, (B) phosphorylated (p) pAKTs473 and (C) the ratio of p:tAKT in quadriceps muscles of male and female $\mathrm{Mstn}^{+/+}\left(\mathrm{M}^{+/+}\right)$,

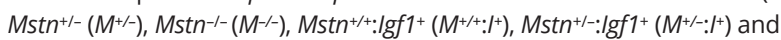
Mstn-1-: $: g 1^{+}\left(M^{-1-: I^{+}}\right)$mice as determined by Western blotting $(n=8$ per genotype and sex, sampled at 12 weeks - study 2). The mean concentration for each group is represented by the horizontal bar. The asterisk indicates a significance between sex for the $M^{++*}: I^{+}$genotype $\left({ }^{\star} P<0.05\right)$.

growth rates, body and muscle mass of male mice were greatly increased when myostatin was absent and IGF1 was present in excess (Hennebry et al. 2017). However, in female mice, a persistent partial refractoriness to IGF1 signalling via AKT may underlie the failure for the full potential growth to become manifest (see below).

Expression of transgenic Igf1Ea mRNA was at least 2-fold greater in quadriceps muscles of males than of females, which may be attributed to the greater abundance of type 2B MyHC myofibres because the MLC/Igf1 transgene is 
expressed in a hierarchical fashion in the order $2 \mathrm{~B}, 2 \mathrm{X}$ and 2A (Shavlakadze et al. 2005). However, there was on average 1.4-fold more IGF1 protein in quadriceps muscles of females. This observation may point to a greater sensitivity of a negative feedback loop to reduce transcription of Igf1Ea mRNA in males, or that there is partial refractoriness to IGF1 in female skeletal muscles (and other tissues). The modest growth of soleus muscles is consistent with reduced expression of $I g f 1 E a$ mRNA and action in type $2 \mathrm{~A}$ myofibres. Soleus muscles are roughly 40\% type I and 60\% type 2A (Augusto et al. 2004).

Concentrations of IGF1 were increased in blood of male but not female mice carrying the $I g f 1$ transgene. This result departs from our previous report (Hennebry et al. 2017), wherein we were unable to resolve differences in concentrations of IGF1 in blood between the six male genotypes. However, we did observe numerical increases in concentrations of IGF1 in blood of $\mathrm{Mstn}^{+/-}: \mathrm{Igf1} 1^{+}$and Mstn-l-:Igf1+ mice. The same assay was used again but with different dilutions to measure the higher concentrations of IGF1 in the transgenic mice. This time, the increased concentrations in IGF1 transgenic males were apparent. It should be noted that the assay does not discriminate between transgenic and endogenous forms of IGF1 but at 12 weeks of age, we speculate that the increased concentrations are due to the presence of the transgene and not due to an increase in endogenous secretion. The increased circulating concentrations of IGF1 in male mice transgenic for $I g f 1$ may contribute to the greater growth in these mice. As noted in the Introduction, while local expression of Igf1 has the predominant effect on growth, circulating concentrations can contribute up to $30 \%$ of post-natal growth and adult body size (Stratikopoulos et al. 2008).

Expression of the Igf1r mRNA had no clear pattern and was not consistently affected by the absence of myostatin or the presence of the IGF1 transgene. However, expression was increased in female quadriceps muscles of $\mathrm{Mstn}^{+/+}$, Mstn $^{+--}: I_{8} 1^{+}$, Mstn $^{-/}$and reduced in muscles of both sexes when myostatin was absent and in the presence of the Igf1 transgene $\left(\right.$ Mstn $\left.^{--}: I g f 1^{+}\right)$. The pattern in males is broadly similar to our previous observation wherein Igf1r mRNA was reduced in male quadriceps muscles of $I g f 1$ transgenic mice (Hennebry et al. 2017). Given that the expression of Igf1r mRNA declines after 6 weeks of age and is low at 12 weeks of age (study 1), when these tissues were collected in study 2, we speculate that the mRNA reflects basal expression in adults rather than expression at peak growth.

The decline in the mass of the gonadal fat pad with the increased lean mass is consistent with a combined effect of the loss of functional myostatin (Hamrick et al. 2006) and an increase in IGF1 (Fiorotto et al. 2003) in promoting a lean phenotype. Myostatin directs the fate of precursor cells towards a lipogenic lineage (Artaza et al. 2005), while IGF1 promotes a myogenic fate via regulating Rho GTPase (Sordella et al. 2003).

Tibia length remained the same within sex and genotype, which is consistent with previous reports (Shimizu \& Awata 1984, Hennebry et al. 2017). Other than the humerus, leg bones do not exhibit sexually dimorphic growth (Shimizu \& Awata 1984). However, the vertebral bones grow at a faster rate in male, than in female mice (Shimizu \& Awata 1984), which is consistent with the longer nose-to-anus length observed in males in the current study and in others (Klover \& Hennighausen 2007).

Normalising the mass of the heart to body mass, or to tibia length raised to the power of 3 , has now been shown to be a better method than to tibia length alone (Hagdorn et al. 2019) and we used this method here. However, the mass of the heart in $\mathrm{Mstn}^{-/}$mice has been reported to be unchanged from WT mice up to 100 days of age (Rodgers et al. 2009). Our data accord with the lack of differences in uncorrected heart mass among genotypes at 12 weeks of age but show that there is a sexually dimorphic difference wherein females have smaller hearts than males. After correcting to body mass though, the differences between sexes disappear. Therefore, the decreased mass of the hearts corrected to body mass in $\mathrm{Mstn}^{-/}$and Mstn-/-: $I g f 1^{+}$are an artefact of greater body mass alone.

We observed that the absence of myostatin together with the presence of transgenic-derived IGF1 altered the myofibre phenotype. The composition of $\mathrm{MyHC}$ in myofibres determines the fast- and slow-twitch characteristics of skeletal muscle. Our current findings accord with those of others who showed that Mstn ${ }^{-/}$ mice have more myofibres expressing type 2 MyHC in the soleus (type 2A) and EDL muscles (types $2 \mathrm{~B}$ and $2 \mathrm{X}$ ) (Girgenrath et al. 2005, Amthor et al. 2007) and that IGF1 directly upregulates the type 2B MyHC promoter (Shanely et al. 2009). Our data also accord with the use of the MLC promoter, which is most active in muscles expressing type 2B MyHC and least in the type $1 \mathrm{MyHC}$ expressing myofibres (Donoghue et al. 1991, Musaro et al. 2001).

The increased abundance of total AKT in conjunction with decreased copy number of Mstn in quadriceps muscles and the increase in phosphorylated AKT in association with mice transgenic for $I g f 1$ is consistent with our previous report (Hennebry et al. 2017). We now report that there is a greater abundance of total AKT in quadriceps in 
females as compared with males, while pAKT ${ }^{5473}$ remains largely unchanged between sexes. Therefore, the ratio of p-t AKT is greater in quadriceps of males than females, which is consistent with sexually dimorphic growth of skeletal muscles. The increased expression of $I g f 1 r$ mRNA in muscles of female mice transgenic for $I g f 1$ is consistent with reduced negative feedback regulation from the decreased activation of AKT, which likely acts on mTORC1 to inhibit and degrade IRS1 (Rozengurt et al. 2014).

It was recently reported that IGF2 may contribute to the hypermuscular muscle development in $\mathrm{Mstn}^{-/}$mice because concentrations of Igf 2 mRNA and protein were higher in muscles of $\mathrm{Mstn}^{-/}$compared with WT mice from 3 to 10 weeks of age (Clark et al. 2015). We did not measure concentrations of $I g f 2$ mRNA or protein in the current study, but presume that they would have been similarly increased in skeletal muscles of $\mathrm{Mstn}^{-/}$mice used here. If so, the increased concentrations of IGF2 protein may have contributed to the additional growth of body and muscle mass in $\mathrm{Mstn}^{-/-}$mice. However, we believe that it is unlikely that IGF2 plays an important role in regulating sexually dimorphic growth given that sexual dimorphism persisted in this study and that by Clark et al. (2015).

In conclusion, we report that excess IGF1, in conjunction with the absence of myostatin, greatly increased the body and muscle mass of both sexes and promoted a leaner phenotype with faster twitch myofibre characteristics. However, neither the absence of myostatin nor excess IGF1 nor the combination of the two overcame, or reduced sexually dimorphic growth. Instead, sexual dimorphism persisted with males remaining consistently larger than females - a phenomenon that is consistent with greater IGF1-induced activation of AKT in skeletal muscles of males.

\section{Declaration of interest}

The authors declare that there is no conflict of interest that could be perceived as prejudicing the impartiality of the research reported.

\section{Funding}

This work was supported by a grant from the Foundation of Research, Science and Technology (New Enterprise Research Fund C10X0703), New Zealand.

\section{Author contribution statement}

C D M, F J, H K S and R P interpreted the data and wrote the manuscript. J $\mathrm{O}, \mathrm{S} \mathrm{F}, \mathrm{KW}, \mathrm{M} \mathrm{T}$ and collected and analysed the data. C D M, K G M and T W conducted the animal experiments.

\section{Acknowledgements}

The authors are grateful to Ric Broadhurst, Bobby Smith, Glenda Smith and Genevieve Sheriff for looking after mice in the Small Animal Colony at Ruakura and to Dr Harold Henderson from AgResearch Ltd for advice with statistics.

\section{References}

Amthor H, Macharia R, Navarrete R, Schuelke M, Brown SC, Otto A, Voit T, Muntoni F, Vrbova G, Partridge T, et al. 2007 Lack of myostatin results in excessive muscle growth but impaired force generation. PNAS 104 1835-1840. (https://doi.org/10.1073/ pnas.0604893104)

Artaza JN, Bhasin S, Magee TR, Reisz-Porszasz S, Shen R, Groome NP, Meerasahib MF \& Gonzalez-Cadavid NF 2005 Myostatin inhibits myogenesis and promotes adipogenesis in C3H 10T(1/2) mesenchymal multipotent cells. Endocrinology 146 3547-3557. (https://doi.org/10.1210/en.2005-0362)

Augusto V, Padovani CR \& Campos GER 2004 Skeletal muscle fiber types in C57BL6J mice. Brazilian Journal of Morphological Sciences 21 89-94.

Baker J, Liu JP, Robertson EJ \& Efstratiadis A 1993 Role of insulin-like growth factors in embryonic and postnatal growth. Cell 75 73-82. (https://doi.org/10.1016/S0092-8674(05)80085-6)

Beilharz MW, Lareu RR, Garrett KL, Grounds MD \& Fletcher S 1992 Quantitation of muscle precursor cell activity in skeletal muscle by Northern blot analysis of MyoD and myogenin expression: application to dystrophic ( $\mathrm{mdx}$ ) mouse muscle. Molecular and Cellular Neurosciences 3 326-331. (https://doi.org/10.1016/10447431(92)90029-2)

Blough ER, Rennie ER, Zhang F \& Reiser PJ 1996 Enhanced electrophoretic separation and resolution of myosin heavy chains in mammalian and avian skeletal muscles. Analytical Biochemistry 233 31-35. (https://doi.org/10.1006/abio.1996.0003)

Callewaert F, Venken K, Kopchick JJ, Torcasio A, van Lenthe GH, Boonen S \& Vanderschueren D 2010 Sexual dimorphism in cortical bone size and strength but not density is determined by independent and time-specific actions of sex steroids and IGF-1: evidence from pubertal mouse models. Journal of Bone and Mineral Research $\mathbf{2 5}$ 617-626. (https://doi.org/10.1359/jbmr.090828)

Clark DL, Clark DI, Hogan EK, Kroscher KA \& Dilger AC 2015 Elevated insulin-like growth factor 2 expression may contribute to the hypermuscular phenotype of myostatin null mice. Growth Hormone and IGF Research 25 207-218. (https://doi.org/10.1016/j. ghir.2015.06.007)

Donoghue MJ, Alvarez JD, Merlie JP \& Sanes JR 1991 Fiber type- and position-dependent expression of a myosin light chain-CAT transgene detected with a novel histochemical stain for CAT. Journal of Cell Biology 115 423-434. (https://doi.org/10.1083/jcb.115.2.423)

Fiorotto ML, Schwartz RJ \& Delaughter MC 2003 Persistent IGF-I overexpression in skeletal muscle transiently enhances DNA accretion and growth. FASEB Journal 17 59-60. (https://doi.org/10.1096/fj.020289fje)

Girgenrath S, Song K \& Whittemore LA 2005 Loss of myostatin expression alters fiber-type distribution and expression of myosin heavy chain isoforms in slow- and fast-type skeletal muscle. Muscle and Nerve 31 34-40. (https://doi.org/10.1002/mus.20175)

Griffin GE \& Goldspink G 1973 The increase in skeletal muscle mass in male and female mice. Anatomical Record 177 465-469. (https://doi. org/10.1002/ar.1091770311)

Hagdorn QAJ, Bossers GPL, Koop AC, Piek A, Eijgenraam TR, van der Feen DE, Sillje HHW, de Boer RA \& Berger RMF 2019 A novel method optimizing the normalization of cardiac parameters in small animal models: the importance of dimensional indexing. American Journal https://joe.bioscientifica.com

https://doi.org/10.1530/JOE-20-0485 (c) 2021 Society for Endocrinology Published by Bioscientifica Ltd. Printed in Great Britain 
of Physiology: Heart and Circulatory Physiology 316 H1552-H1557. (https://doi.org/10.1152/ajpheart.00182.2019)

Hamalainen N \& Pette D 1993 The histochemical profiles of fast fiber types IIB, IID, and IIA in skeletal muscles of mouse, rat, and rabbit. Journal of Histochemistry and Cytochemistry 41 733-743. (https://doi org/10.1177/41.5.8468455)

Hamrick MW, Pennington C, Webb CN \& Isales CM 2006 Resistance to body fat gain in 'double-muscled' mice fed a high-fat diet. International Journal of Obesity 30 868-870. (https://doi.org/10.1038/ sj.ijo.0803200)

Handelsman DJ, Spaliviero JA, Scott CD \& Baxter RC 1987 Hormonal regulation of the peripubertal surge of insulin-like growth factor-I in the rat. Endocrinology 120 491-496. (https://doi.org/10.1210/endo120-2-491)

Hennebry A, Oldham J, Shavlakadze T, Grounds MD, Sheard P, Fiorotto ML, Falconer S, Smith HK, Berry C, Jeanplong F, et al. 2017 IGF1 stimulates greater muscle hypertrophy in the absence of myostatin in male mice. Journal of Endocrinology 234 187-200. (https://doi.org/10.1530/JOE-17-0032)

$\mathrm{Hu}$ Z, Friberg RD \& Barkan AL 1993 Ontogeny of GH mRNA and GH secretion in male and female rats: regulation by GH-releasing hormone. American Journal of Physiology 265 E236-E242. (https://doi. org/10.1152/ajpendo.1993.265.2.E236)

Hwa V 2016 STAT5B deficiency: impacts on human growth and immunity. Growth Hormone and IGF Research 28 16-20. (https://doi. org/10.1016/j.ghir.2015.12.006)

Klover P \& Hennighausen L 2007 Postnatal body growth is dependent on the transcription factors signal transducers and activators of transcription $5 \mathrm{a} / \mathrm{b}$ in muscle: a role for autocrine/paracrine insulinlike growth factor I. Endocrinology 148 1489-1497. (https://doi. org/10.1210/en.2006-1431)

Klover P, Chen W, Zhu BM \& Hennighausen L 2009 Skeletal muscle growth and fiber composition in mice are regulated through the transcription factors STAT5a/b: linking growth hormone to the androgen receptor. FASEB Journal 23 3140-3148. (https://doi. org/10.1096/fj.08-128215)

Kofoed EM, Hwa V, Little B, Woods KA, Buckway CK, Tsubaki J, Pratt KL, Bezrodnik L, Jasper H, Tepper A, et al. 2003 Growth hormone insensitivity associated with a STAT5b mutation. New England Journal of Medicine 349 1139-1147. (https://doi.org/10.1056/ NEJMoa022926)

Le Roith D, Bondy C, Yakar S, Liu JL \& Butler A 2001 The somatomedin hypothesis: 2001. Endocrine Reviews 22 53-74. (https://doi. org/10.1210/edrv.22.1.0419)

Lee SJ \& McPherron AC 1999 Myostatin and the control of skeletal muscle mass. Current Opinion in Genetics and Development 9 604-607. (https://doi.org/10.1016/s0959-437x(99)00004-0)

Liu JL \& LeRoith D 1999 Insulin-like growth factor I is essential for postnatal growth in response to growth hormone. Endocrinology 140 5178-5184. (https://doi.org/10.1210/endo.140.11.7151)

Liu JP, Baker J, Perkins AS, Robertson EJ \& Efstratiadis A 1993 Mice carrying null mutations of the genes encoding insulin-like growth factor I (Igf-1) and type 1 IGF receptor (Igf1r). Cell 75 59-72. (https:// doi.org/10.1016/S0092-8674(05)80084-4)

Lundby C, Nordsborg N, Kusuhara K, Kristensen KM, Neufer PD \& Pilegaard H 2005 Gene expression in human skeletal muscle: alternative normalization method and effect of repeated biopsies. European Journal of Applied Physiology 95 351-360. (https://doi. org/10.1007/s00421-005-0022-7)

Lupu F, Terwilliger JD, Lee K, Segre GV \& Efstratiadis A 2001 Roles of growth hormone and insulin-like growth factor 1 in mouse postnatal growth. Developmental Biology 229 141-162. (https://doi.org/10.1006/ dbio.2000.9975)

Mathews LS, Hammer RE, Brinster RL \& Palmiter RD 1988 Expression of insulin-like growth factor I in transgenic mice with elevated levels of growth hormone is correlated with growth. Endocrinology $\mathbf{1 2 3}$ 433-437. (https://doi.org/10.1210/endo-123-1-433)

McMahon CD, Popovic L, Jeanplong F, Oldham JM, Kirk SP, Osepchook CC, Wong KW, Sharma M, Kambadur R \& Bass JJ 2003 Sexual dimorphism is associated with decreased expression of processed myostatin in males. American Journal of Physiology: Endocrinology and Metabolism 284 E377-E381. (https://doi. org/10.1152/ajpendo.00282.2002)

McPherron AC, Lawler AM \& Lee SJ 1997 Regulation of skeletal muscle mass in mice by a new TGF-beta superfamily member. Nature $\mathbf{3 8 7}$ 83-90. (https://doi.org/10.1038/387083a0)

Morissette MR, Cook SA, Buranasombati C, Rosenberg MA \& Rosenzweig A 2009 Myostatin inhibits IGF-I-induced myotube hypertrophy through Akt. American Journal of Physiology: Cell Physiology 297 C1124-C1132. (https://doi.org/10.1152/ ajpcell.00043.2009)

Musaro A, McCullagh K, Paul A, Houghton L, Dobrowolny G, Molinaro M, Barton ER, Sweeney HL \& Rosenthal N 2001 Localized Igf- 1 transgene expression sustains hypertrophy and regeneration in senescent skeletal muscle. Nature Genetics 27 195-200. (https://doi. org/10.1038/84839)

Oldham JM, Osepchook CC, Jeanplong F, Falconer SJ, Matthews KG, Conaglen JV, Gerrard DF, Smith HK, Wilkins RJ, Bass JJ, et al. 2009 The decrease in mature myostatin protein in male skeletal muscle is developmentally regulated by growth hormone. Journal of Physiology 587 669-677. (https://doi.org/10.1113/jphysiol.2008.161521)

Paul RG, Hennebry AS, Elston MS, Conaglen JV \& McMahon CD 2019 Regulation of murine skeletal muscle growth by STAT5B is age- and sex-specific. Skeletal Muscle 9 19. (https://doi.org/10.1186/s13395-0190204-3)

Rebbapragada A, Benchabane H, Wrana JL, Celeste AJ \& Attisano L 2003 Myostatin signals through a transforming growth factor beta-like signaling pathway to block adipogenesis. Molecular and Cellular Biology 23 7230-7242. (https://doi.org/10.1128/mcb.23.20.72307242.2003)

Reisz-Porszasz S, Bhasin S, Artaza JN, Shen R, Sinha-Hikim I, Hogue A, Fielder TJ \& Gonzalez-Cadavid NF 2003 Lower skeletal muscle mass in male transgenic mice with muscle-specific overexpression of myostatin. American Journal of Physiology: Endocrinology and Metabolism 285 E876-E888. (https://doi.org/10.1152/ajpendo.00107.2003)

Retamales A, Zuloaga R, Valenzuela CA, Gallardo-Escarate C, Molina A \& Valdes JA 2015 Insulin-like growth factor-1 suppresses the myostatin signaling pathway during myogenic differentiation. Biochemical and Biophysical Research Communications 464 596-602. (https://doi. org/10.1016/j.bbrc.2015.07.018)

Rodgers BD, Interlichia JP, Garikipati DK, Mamidi R, Chandra M, Nelson OL, Murry CE \& Santana LF 2009 Myostatin represses physiological hypertrophy of the heart and excitation-contraction coupling. Journal of Physiology 587 4873-4886. (https://doi. org/10.1113/jphysiol.2009.172544)

Rogers P \& Webb GP 1980 Estimation of body fat in normal and obese mice. British Journal of Nutrition 43 83-86. (https://doi.org/10.1079/ bjn19800066)

Rommel C, Bodine SC, Clarke BA, Rossman R, Nunez L, Stitt TN, Yancopoulos GD \& Glass DJ 2001 Mediation of IGF-1-induced skeletal myotube hypertrophy by PI(3)K/Akt/mTOR and PI(3)K/Akt/GSK3 pathways. Nature Cell Biology 3 1009-1013. (https://doi.org/10.1038/ ncb1101-1009)

Rosenthal N, Kornhauser JM, Donoghue M, Rosen KM \& Merlie JP 1989 Myosin light chain enhancer activates muscle-specific, developmentally regulated gene expression in transgenic mice. PNAS 86 7780-7784. (https://doi.org/10.1073/pnas.86.20.7780)

Rozengurt E, Soares HP \& Sinnet-Smith J 2014 Suppression of feedback loops mediated by PI3K/mTOR induces multiple overactivation of compensatory pathways: an unintended consequence leading to drug https://joe.bioscientifica.com

https://doi.org/10.1530/JOE-20-0485 (c) 2021 Society for Endocrinology Published by Bioscientifica Ltd. Printed in Great Britain 
resistance. Molecular Cancer Therapeutics 13 2477-2488. (https://doi org/10.1158/1535-7163.MCT-14-0330)

Safranski TJ, Lamberson WR \& Keisler DH 1993 Correlations among three measures of puberty in mice and relationships with estradiol concentration and ovulation. Biology of Reproduction 48 669-673. (https://doi.org/10.1095/biolreprod48.3.669)

Shanely RA, Zwetsloot KA, Childs TE, Lees SJ, Tsika RW \& Booth FW 2009 IGF-I activates the mouse type IIb myosin heavy chain gene. American Journal of Physiology: Cell Physiology 297 C1019-C1027. (https://doi. org/10.1152/ajpcell.00169.2009)

Shavlakadze T, Winn N, Rosenthal N \& Grounds MD 2005 Reconciling data from transgenic mice that overexpress IGF-I specifically in skeletal muscle. Growth Hormone and IGF Research 15 4-18. (https:// doi.org/10.1016/j.ghir.2004.11.001)

Shavlakadze T, Chai J, Maley K, Cozens G, Grounds G, Winn N, Rosenthal N \& Grounds MD 2010 A growth stimulus is needed for IGF-1 to induce skeletal muscle hypertrophy in vivo. Journal of Cell Science 123 960-971. (https://doi.org/10.1242/jcs.061119)

Shimizu H \& Awata T 1984 Growth of skeletal bones and their sexual differences in mice. Jikken Dobutsu 33 69-76. (https://doi. org/10.1538/expanim1978.33.1_69)

Sjogren K, Liu JL, Blad K, Skrtic S, Vidal O, Wallenius V, LeRoith D, Tornell J, Isaksson OG, Jansson JO, et al. 1999 Liver-derived insulinlike growth factor I (IGF-I) is the principal source of IGF-I in blood but is not required for postnatal body growth in mice. PNAS 96 7088-7092. (https://doi.org/10.1073/pnas.96.12.7088)

Smith HK, Matthews KG, Oldham JM, Jeanplong F, Falconer SJ, Bass JJ, Senna-Salerno M, Bracegirdle JW \& McMahon CD 2014 Translational signalling, atrogenic and myogenic gene expression during unloading and reloading of skeletal muscle in myostatin-deficient mice. PLoS ONE 9 e94356. (https://doi.org/10.1371/journal.pone.0094356)
Sordella R, Jiang W, Chen GC, Curto M \& Settleman J 2003 Modulation of Rho GTPase signaling regulates a switch between adipogenesis and myogenesis. Cell 113 147-158. (https://doi.org/10.1016/s00928674(03)00271-x)

Stratikopoulos E, Szabolcs M, Dragatsis I, Klinakis A \& Efstratiadis A 2008 The hormonal action of IGF1 in postnatal mouse growth. PNAS 105 19378-19383. (https://doi.org/10.1073/pnas.0809223105)

Trendelenburg AU, Meyer A, Rohner D, Boyle J, Hatakeyama S \& Glass DJ 2009 Myostatin reduces Akt/TORC1/p70S6K signaling, inhibiting myoblast differentiation and myotube size. American Journal of Physiology: Cell Physiology 296 C1258-C1270. (https://doi. org/10.1152/ajpcell.00105.2009)

Udy GB, Towers RP, Snell RG, Wilkins RJ, Park SH, Ram PA, Waxman DJ \& Davey HW 1997 Requirement of STAT5b for sexual dimorphism of body growth rates and liver gene expression. PNAS 94 7239-7244. (https://doi.org/10.1073/pnas.94.14.7239)

Welle S, Burgess K \& Mehta S 2009 Stimulation of skeletal muscle myofibrillar protein synthesis, p70 S6 kinase phosphorylation, and ribosomal protein $\mathrm{S} 6$ phosphorylation by inhibition of myostatin in mature mice. American Journal of Physiology: Endocrinology and Metabolism 296 E567-E572. (https://doi.org/10.1152/ ajpendo.90862.2008)

White Z, Terrill J, White RB, McMahon C, Sheard P, Grounds MD \& Shavlakadze T 2016 Voluntary resistance wheel exercise from mid-life prevents sarcopenia and increases markers of mitochondrial function and autophagy in muscles of old male and female C57BL/6J mice. Skeletal Muscle 6 45. (https://doi.org/10.1186/s13395-016-0117-3)

Yakar S, Liu JL, Stannard B, Butler A, Accili D, Sauer B \& LeRoith D 1999 Normal growth and development in the absence of hepatic insulinlike growth factor I. PNAS 96 7324-7329. (https://doi.org/10.1073/ pnas.96.13.7324)

Received in final form 26 November 2020

Accepted 8 December 2020

Accepted Manuscript published online 9 December 2020 (c) 2021 Society for Endocrinology Published by Bioscientifica Ltd. 